\title{
ANTAGONIST DISCRIMINATION BETWEEN GANGLIONIC AND ILEAL MUSCARINIC RECEPTORS
}

\author{
D.A. BROWN, A. FORWARD \& S. MARSH
}

Department of Pharmacology, The School of Pharmacy, University of London, 29/39 Brunswick Square, London, WCIN 1AX

The effects of four antagonists on the depolarization of isolated superior cervical ganglia and the contraction of isolated ileal segments of the rat were compared. $\mathrm{pA}_{2}$ values estimated from Schild plots indicated significantly higher affinities of stercuronium $(\times 100)$ and pirenzepine $(\times 23)$ and a significantly lower affinity of 4-diphenylacetoxy- $N$-methylpiperidine methiodide $(\times 0.39)$ for the ganglion than for the ileum. The affinities of $\mathrm{N}$-methylscopolamine for the two tissues were not significantly different. It is concluded that the two types of muscarinic receptor are not identical.

Introduction We have recently compared the muscarinic receptors responsible for depolarizing rat sympathetic ganglion cells with those mediating contraction of the rat isolated ileum (Brown, Fatherazi, Garthwaite \& White, 1980). Although differences in agonist activity were detectable, the conventional muscarinic antagonists atropine, hyoscine and lachesine were equally effective at both sites. However, divergences between peripheral muscarinic receptors have been revealed with other antagonists. Thus, 4diphenylacetoxy- $N$-methylpiperidine (Barlow, Berry, Glenton, Nikolaou \& Soh, 1976) and its methiodide derivative (Barlow, Burston \& Vis, 1980) were 5 and 11 times more potent respectively on the guinea-pig ileum than on the atrium, whereas the neuromuscular blocking agent, stercuronium, appears to show the opposite discrimination (Li \& Mitchelson, 1979). Also, Hammer, Berrie, Birdsall, Burgen \& Hulme (1980) showed that pirenzepine is 5 to 30 times more potent in inhibiting $\left[{ }^{3} \mathrm{H}\right]-N$-methylscopolamine binding to brain tissue than to either cardiac or smooth muscle tissues, whereas the apparent affinities of $N$-methylscopolamine itself only varied by a factor of 2 to 5 .

In view of these observations, we have compared the antagonist activities of $N$-methylscopolamine (NMS), pirenzepine (PZP), 4-diphenylacetoxy- $N$ methylpiperidine methiodide (4-DAMP) and stercuronium (ST) on the muscarinic receptors of the isolated ganglion and ileum of the rat. We find that the latter three agents discriminate beiween these receptors.

Methods Experiments were performed essentially as described by Brown et al. (1980). Superior cervical ganglia were isolated from rats anaesthetized with urethane and ganglion depolarization measured differentially between the ganglion and postganglionic trunk. Instead of the superfusion method used previously, the preparation was placed in a three-chambered bath (Brown \& Marsh, 1978). This had the advantage that the ganglion was totally immersed in flowing Krebs solution, ensuring better temperature control. Ileal segments were removed from killed rats and maintained in $10 \mathrm{ml}$ baths; contractions were recorded with a frontal writing lever loaded to $1 \mathrm{~g}$ tension. Although ilea and ganglia were obtained from different animals, the animals were matched for strain and weight and experiments on the two tissues alternated. Both tissues were maintained in Krebs solution at $29 \pm 0.5^{\circ} \mathrm{C}$ bubbled with $95^{\circ} \% \mathrm{O}_{2}$ and $5 \%$ $\mathrm{CO}_{2}$.

'Semi-cumulative' dose-response curves to ascending concentrations of ( \pm )-muscarine (Brown et al., 1980) were obtained before and after adding an antagonist. All curves were repeated at least twice and 0.5 to $1.5 \mathrm{~h}$ allowed for equilibration with an antagonist. Between one and three ascending concentrations of antagonist were tested in each experiment. No attempt at recovery was made; instead, the drift of the control dose-response curve over comparable time periods was assessed in separate experiments.

Dose-ratios (DR) for antagonist-induced shifts in the dose-response curves were estimated, Schild plots (Arunlakshana \& Schild, 1959) constructed, and $\mathrm{pA}_{2}$ values were determined from least-squares estimates of the resultant regression lines. Dose-ratios less than 3 were excluded from regression analysis, to minimize any influence of sensitivity drifts.

( \pm )-Muscarine iodide was purchased from Sigma. $N$-methylscopolamine (NMS), 4-diphenylacetoxy-Nmethylpiperidine methiodide hydrochloride (4DAMP), pirenzepine (PZP) and stercuronium (ST) were gifts from Drs N.J.M. Birdsall (N.I.M.R., London), R.B. Barlow (Pharmacology Department, Bristol University), R. Hammer (Biochemistry Department, Dr Karl Thomae GmbH, Biberach an der Riss, FRG) and D.W. Straughan (Glaxo Group Research Ltd.) respectively.

Results Figure 1 shows Schild plots for NMS. PZP 


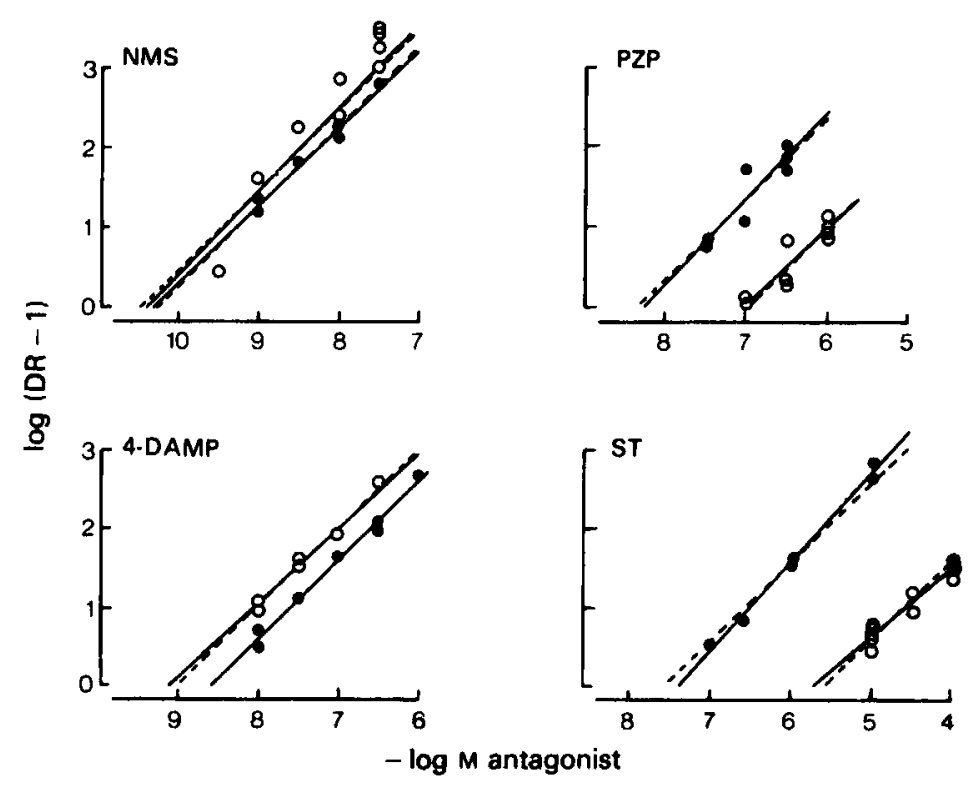

Figure 1. Schild plots for the antagonism of muscarine-induced depolarization of rat isolated ganglia (O) and contractions of rat isolated ileal segments $(O)$ by $N$-methylscopolamine (NMS), pirenzepine (PZP), 4-diphenylacetoxy- $N$-methylpiperidine methiodide (4-DAMP) and stercuronium (ST). Ordinates: $\log (\mathrm{DR}-1)$ where DR $=$ doseratio measured from the displacement of the muscarine dose-response curve by antagonist. Abscissae: negative logarithm of the molar concentration of antagonist. Solid lines are least-squares estimates of the regression times allowing both slope and intercept to vary; dashed lines are estimates at fixed (unity) slope.

4-DAMP and ST on the two preparations. Mean slopes for NMS, PZP and 4-DAMP on both preparations (between 1.08 and 0.95 ) were not significantly different from unity; slopes for ST (ganglion, $1.15 \pm$ s.e. $0.05, n=6$; ileum, $0.87 \pm$ s.e. $0.08, n=13$ ) differed slightly from unity. Since the use of the Schild plot presupposes competitive inhibition, all slopes were constrained to unity and mean $\mathrm{pA}_{2}$ values calculated from least-square estimates of the intercept on the abscissae at $\log (D R-1)=0$ (see Tallarida, Cowan \& Adler, 1979).

Mean $\mathrm{pA}_{2}$ values \pm s.e. ( $n$ in parentheses) were as follows: NMS: ganglion, $10.26 \pm 0.04$ (6); ileum, $10.47 \pm 0.10$ (9); PZP: ganglion, $8.36 \pm 0.09$ (7); ileum, $6.99 \pm 0.08$ (7); 4-DAMP: ganglion, $8.61 \pm 0.04(8)$; ileum, $9.02 \pm 0.04$ (9); ST: ganglion, $7.59 \pm 0.04$ (6): ileum, $5.58 \pm 0.03$ (13).

Relaxing the unity-slope constraint modified the values for ST to $7.40 \pm 0.03$ (ganglion) and $5.73 \pm 0.04$ (ileum). Differences between the $\mathrm{pA}_{2}$ values on the two tissues were highly significant $(P<0.001$, two-tailed $t$ test $)$ for PZP, 4-DAMP and ST; the difference with NMS was not significant $(P$ $0.1>0.05$ ).

Discussion These experiments suggest that the muscarinic receptors in the rat ganglion are not identical with those in the rat ileum. Although equally sensitive to atropine, hyoscine (Brown et al., 1980) and NMS (present experiments), the other antagonists tested showed quite wide variations in $\mathrm{pA}_{2}$ on the two tissues. Thus, ST and PZP were appreciably more effective on the ganglion than on the ileum (by 100 and 23 times respectively), whereas 4-DAMP was significantly less effective on the ganglion.

The antagonist potencies of 4-DAMP and PZP on the rat ileum agree quite well with those on the guinea-pig ileum (Barlow et al., 1980; M.P. Caulfield, personal communication). However, the absolute $\mathrm{pA}_{2}$ values for PZP and NMS on the intact ileum yield $K_{1}$ values about an order of magnitude smaller than those determined by radiolabelled ligand-binding to homogenized tissues (see Hammer et al., 1980). The meaning of this difference is unclear.

Irrespective of absolute values, the wide variations in the relative activity of the different antagonists on the two tissues confirm the heterogeneity of peripheral muscarinic receptors (Hammer et al., 1980; Barlow et al., 1980). Comparison with the binding studies of Hammer et al. (1980) suggest that ganglionic muscarinic receptors may be akin to the high affinity sites in the central nervous system in terms of their sensitivity to PZP ris-a-tis smooth muscle. This 
would accord with the comparable electrophysiological responses of the two types of neurone to muscarinicreceptor activation (see Brown \& Constanti, 1980, for references). It would be helpful to know if this parallel extends to other antagonists.

This work was aided by a grant from the Medical Research Council. We thank Dr N.J.M. Birdsalt, Dr R.B. Barlow, Dr R. Hammer and Dr D.W. Straughan for gifts of drugs. We also thank Drs Birdsall and Straughan, and Dr M.P. Caulfield (Glaxo Group Research Ltd.) for fruitful discussion.

\section{References}

Arunlakshana, O. \& Schild, H.O. (1959). Some quantitative uses of drug antagonists. Br. J. Pharmac. Chemother., 14, 48-58.

Barlow, R.B., Berry, K.J., Glenton, P.A.M., Nikolaou, N.M. \& SOH, K.S. (1976). A comparison of affinity constants for muscarine-sensitive acetylcholine receptors in guinea-pig atrial pacemaker cells at $29^{\circ} \mathrm{C}$ and in ileum at $29^{\circ} \mathrm{C}$ and $37^{\circ} \mathrm{C}$. Br. J. Pharmac., 58, 613-620.

Barlow, R.B., Burston, K.N. \& VIS, A. (1980). Three types of muscarinic receptors? Br. J. Pharmac., 68, 141-142P.

Brown, D.A. \& Constanti, A. (1980). Intracellular observations on the effects of muscarinic agonists on rat sympathetic neurones. Br. $J$. Pharmac. (in press).

Brown, D.A., Fatherazi. S., Garthwaite, J. \& White,
Note added in proof

In general agreement with the above conclusions, R. Hammer (1980, Scand. J. Gastroenterol, in press) found that pirenzepine is 20 times more effective in displacing $\left[{ }^{3} \mathrm{H}\right]$-NMS binding to homogenates of bovine sympathetic ganglia $\left(K_{1} 2 \times 10^{-7} \mathrm{M}\right)$ than to dog fundic smooth muscle homogenates $\left(K_{1} 1 \times 10^{-6} \mathrm{M}\right)$.

C.K. Li \& F. Mitchelson (1980, Br. J. Pharmac., 70. 313-321) have also just shown that stercuronium is more effective on rabbit postganglionic sympathetic prejunctional muscarinic receptors (to which the ganglionic receptors may be analogous) than on guinea-pig smooth muscle preparations.

R.D. (1980). Muscarinic receptors in rat sympathetic ganglia. Br. J. Pharmac., (in press).

BRown, D.A. \& Marsh, S. (1978). Axonal GABA-receptors in mammalian peripheral nerve trunks. Brain Res., 156, 187-191.

Hammer, R., Berrie, C.P., Birdsall, N.J.M., Burgen, A.S.V. \& HuLme, E.C. (1980). Pirenzepine distinguishes between different subclasses of muscarinic receptors. Nature, 283, 90-92.

L1, C.K. \& Mitchelson, F. (1979). Selective inhibition of muscarinic receptors. Clin. exp. Pharm. Physiol., 6, 641.

Tallarida, R.J., Cowan, A. \& Adler, M.W. (1979). pA and receptor differentiation: a statistical analysis of competitive antagonism. Life Sci., 25, 637-654. 